\title{
The Positive Feedback Advantages of Combining Buying and Investing
}

\author{
Vic Norris ${ }^{1}$, Laura Norris ${ }^{1}$, Wing-Keung Wong2 \\ ${ }^{1}$ LMSM EA4312, University of Rouen, Mont Saint Aignan, France \\ ${ }^{2}$ Hong Kong Baptist University, WLB, Shaw Campus, Hong Kong, China \\ Email: victor.norris@univ-rouen.fr
}

Received 23 July 2015; accepted 23 October 2015; published 27 October 2015

Copyright (C) 2015 by authors and Scientific Research Publishing Inc.

This work is licensed under the Creative Commons Attribution International License (CC BY). http://creativecommons.org/licenses/by/4.0/

(c) (i) Open Access

\begin{abstract}
A substantial proportion of the world's population is dissatisfied with the way the global marketbased economy operates. In particular, the desire of consumers to pay as little as possible for a product and the desire of producers and investors to make as much profit as possible, lead to actions that drive down wages, undermine social welfare and damage the environment. To counteract this, we propose that the millions of consumers who wish to change the market adopt a combined buying and investing strategy that we term buyvesting in which "ethical" would become the new "profitable". We use a learning program to illustrate the buyvesting proposal, which we discuss with respect to the concepts of competitive coherence and shared reality theory.
\end{abstract}

\section{Keywords}

\section{Investment, Finance, Competition, Neural network, Board}

\section{Introduction}

According to one popular description "A market-based economy is where goods and services are produced without obstruction or interference etc." [1], this absence of constraints results in several questions that trouble millions of potential investors. How can they buy the cheapest products and yet preserve decent working conditions, ensure taxes are paid, and protect the environment? How can they make money from ethical investments? Such altruistic motivation leads large numbers of internauts to attempt to change the behavior of companies via online petitions, orchestrated boycotts and political activism. This altruism is itself at complete variance with the values driving the global economy and therefore risks being ineffectual. Indeed, the attempts of those who wish to change the global market are often restricted to specific actions and have little effect on its overall functioning.

${ }^{*}$ Corresponding author. 
Income disparity has attracted considerable attention as a possible factor in generating a wide range of social ills [2]-[7] and in reflecting how such disparity might be reduced, the authors cite those economists who "sometimes suggest that the market is like a democratic voting system: our expenditure is in effect our vote on how productive resources should be allocated between competing demands" [5]; the idea, then, is that the rich have more effective votes than the poor and can distort economies. In line with the market approach to improving society, organizations such as Ceres [8] help direct the investment of trillions of dollars with the aim of improving working conditions and reducing environmental damage (see below).

Here, we propose a possible answer to those who are looking for a peaceful and effective way to alter the operation of the global market. We examine the nature of one of the fundamental social and environmental problems that results from the pressure to minimize costs and maximize profits. We discuss how the combination of buying and investing via a common institution may circumvent this problem. Neural networks have been widely used in economics [9] and, finally, we use a type of neural network to try to evaluate the efficacy of this combination of buying and investing [10].

\section{The Nature of the "Cheapest Takes All" Problem}

It has been claimed recently [11] that "Starting in 1994, NAFTA and other trade deals wiped out most taxes on foreign-made clothing, while doing nothing to protect worker rights or the environment abroad. Overnight, American workers had to compete with countries that tolerated child labor, 16-hour workdays and 40-cent-anhour wages. The result? 750,000 U.S. jobs evaporated in favor of sweatshops and a race to the global bottom”. The dominant ethic in the global market-based economy is that it is right to maximize short-term profits by minimizing costs. This leads to the selective process of the "cheapest takes all” whereby consumers generally buy cheaper goods and services and, in consequence, those supplying such goods and services prosper by undercutting those supplying more expensive ones. Decreasing the price of goods and services can be obtained by decreasing wages, by reducing welfare and health provisions, and, in the short-term, by damaging the environment. In an economy operating "without obstruction or interference" in which it does not matter how cheapness is obtained, a vicious circle can be created from the combination of buying the cheapest and supplying the cheapest. The end result is likely to be a system based on an effective slavery with the additional risk of environmental catastrophes leading, in the worst case scenario, to the extinction of the human species itself. It has been noted that "streamlining of production for efficiency and cost savings may have a role in emergence of new infections when biological materials are the basis for product formulation" with the example of the manufacture of blood factor concentrates via pooling plasma from many donors such that "the entire pool could be contaminated by a single unit from an HIV-infected donor”. Dr. Michael Rodell, former vice-president of the Armour Pharmaceutical Company, estimated that four infected persons could contaminate the entire world supply of factor VIII [12]. On a bigger scale, a yielding to the pressure for short-term profit was behind the pooling of animal products and their redistribution in the form of bone and marrow meal (along with changes to the rendering process); this led to the number of people potentially affected with Mad Cow Disease estimated, at one time, at several orders of magnitude [13]. The unfettered drive for short-term profit may also result in events threatening the human species via global warming [14] and pollution [15] [16].

\section{The Difficulty of the Problem}

The involvement of competitive coherence is one reason why solving the problem of the "cheapest takes all” process is difficult. The concept of competitive coherence originates in the fact that biological systems on all scales are confronted with the challenge of obtaining a future state that is coherent with their environment and with their previous states [17]. These states are created by the active functioning of a subset of constituents of the system. This active subset is selected from the larger set available to the system. Many social organizations are constrained by the need to reconcile 1) coherence with their present environment and 2) coherence with their past environments. Companies and financial institutions, for example, have to select a Board-an active subset-of directors in response to political, legal, economic, technical and social changes but must reconcile this selection with the history of the organization which includes its products, clients, reputation, and workforce skills. Such selection entails both the generation of a coherent Board, in which the people on the Board work together efficiently and harmoniously, and the generation of a coherent sequence of Board members. Incoherence and contradictory behavior occurring at any one time are punished since a Board that has members who 
disagree to the extent that, for example, the Board decides to try simultaneously to both increase and decrease the company's product range is likely to be out-competed by competitors whose Board agrees on a single strategy. Temporal incoherence, that is, inconsistent behavior occurring over a period of time, is also punished; for example, a Board that changed all its members without reference to the previous Board might make decisions that would lead to the company going from one marketing/production strategy in one year to another very different strategy in the following year. A strong selective pressure, therefore, exists in the competitive market favoring companies that select Board members so as to have Boards that make both coherent decisions and a coherent sequence of such decisions. We have proposed that competitive coherence is responsible for generating active subsets of elements, whether these elements are genes in the case of bacteria or Board members in the case of companies, from a much larger ensemble of elements [18]. The concept of competitive coherence is based on the way a system must maintain both the continuity of the composition of its active subset via a Next process and the coherence of this active subset (with respect to the inside and outside world) via a Now process. In an in silico implementation of this concept, the state of a system at time $n+1$ is determined by a competition between the Next process, which is based on its state at time n, and the Now process, which is based on the developing $n+1$ state itself [10]. This implementation shows first that competitive coherence can lead to a network of connections that constitutes learning and second that this network of connections is robust with respect to noise and is self-perpetuating.

How is the above relevant to the "cheapest takes all” problem in a company or financial organization? One reason why finding a solution to the problem is difficult is provided by shared reality theory. In this theory, people seek out others who validate and strengthen their beliefs whilst the relationships between people are established and maintained if they involve shared beliefs [19]. This means that if those who manage and invest in companies share a belief in the inevitability that the "cheapest takes all"—and even in its desirability—this belief will be maintained within this sector of the financial community. Indeed, a willingness to express this belief may be a condition for membership of the community. A positive feedback then exists whereby those who belong to the group making the decisions to maximize profits "without obstruction or interference" can only belong to this group if they think (or act as if they think) that profits should be maximized "without obstruction or interference".

An overlap here with competitive coherence may be apparent if one considers the problem of selecting the Board (the active subset) each week from a larger set of potential Board members. A Next process might be the tendency for someone who is on the Board one year to be someone who is on the Board next year. A Now process might be the coherence of the Board with respect to itself (the Board may need an accountant, a technical director and a sales director) and with respect to the market and its competitors (if part of the production has been relocated to another country, the Board may need members with experience of this country). It might be argued that one of the most important Now and Next connections leading to membership of the decision-making group is a shared ethic of maximizing profits without let or hindrance.

Finding a political solution to the "cheapest takes all" problem is difficult in part because of the domination of the media by a limited number of companies that, again, possess self-perpetuating ethics. Such ethics can even lead them into an unsustainable denial of reality, as in the case of climate change [20]. This domination by the few makes it easy to promote the idea that the scenario of the "cheapest takes all" is inevitable and that attempts to find a solution are therefore doomed to fail.

\section{The Buyvesting Hypothesis}

A potential solution to the problems raised by the ubiquity of the "cheapest takes all" process would be to combine buying and investing in a positive feedback relationship. We term this strategy, buyvesting, the structure in which it might operate a buyvestment fund and the members of this fund, buyvestors. The goal of buyvesting would be to drive companies into improving salaries, respecting the environment and paying taxes.

How would buyvesting work? The buyvestment fund would both lend money to selected companies and buy shares in these companies. These activities would depend on the company respecting the buyvestment fund's conditions on employment, the environment and taxation. The fund would therefore negotiate with these companies before investing and would maintain close contacts with them once it had invested. The buyvestors themselves would provide money for the buyvestment fund to invest in the companies from which they buy and, reciprocally, would buy from the companies in which they invest. The fundamental point is that these companies 
would be the same. Their profits should rise because they would benefit from both increased investment and increased sales. They would have the edge over their competitors that did not respect the buyvestment fund's conditions. Moreover, buyvestment companies would benefit from more than a temporary increase in investment and sales: they would benefit from the long-term support of the buyvestors. The buyvestor, who is an investor as well as a consumer, would also make money. At the same time, the buyvestor would help improve social and environmental conditions.

\section{Evidence that Buyvesting Might Work}

\subsection{Buyvesting Could Benefit from Millions of Activists}

Buyvesting depends on turning millions of buyers into buyvestors. Evident candidates for buyvestors include those on the political Left militating for a major change in society. In France, for example, those expressing a willingness to vote for the Front de Gauche, constituted around 10\% of the electorate during the 2012 presidential elections [21]. Are such electors likely to turn their opinions into economic actions? According to a You Gov opinion poll [22], 27 per cent of respondents in the UK said that "there are companies I actively boycott because they don't pay enough tax". Campaigns based on boycotting can be effective but are essentially negative, shortterm and confined to a few companies. Nevertheless, millions of internauts do attempt to change the behavior of companies via a myriad organizations that include Sum Of Us, Care2 Causes, Demand Progress, ONE, Our World Our Say, Change, Avaaz and, of course, political parties. A buyvestment fund could benefit from the support of these activists by offering them a peaceful, effective and financially rewarding way to change company strategies. One encouraging example of this is the phone company, CREDO, which openly militates for a variety of causes and which has donated more than $\$ 78$ million over the last thirty years [23].

\subsection{The Importance of the Internet}

Turning millions of buyers into buyvestors would be greatly facilitated by the internet which would enable them to be informed and organized. The internet would also allow them to act effectively. Indeed, use of the internet by pressure groups reveals just how vulnerable companies are to public opinion. According to Care2.com, "Social media have given consumers a place to publicly air their concerns and call out the companies they think are doing wrong. Before, if a customer had a complaint, they could contact the company privately and have it dealt with that way. Now anytime someone sees something in a product they don't like, they can garner support and petition signatures in the thousands. For example, though PepsiCo Inc. has removed brominated vegetable oil from Gatorade, Coca-Cola has not done the same with the Powerade drinks that contain that ingredient. An online petition to have brominated vegetable oil was reported to have had 57,000 supporters "as of last week" [24]. This was followed in 2014 by the declaration from Coca-Cola that it would be removing the compound from all its drinks [25]. In addition to these individual actions, consumer dissatisfaction is now taking on a more general form with the emergence of sites and applications such as BlackListic which allows customers to describe the problem they have encountered and the resolution to this problem, if any, to be published [26].

\subsection{Buyvestors Speak the Language of Capitalism}

Buyvesting would exploit the amoral essence of the modern, dominant form of capitalism, that making money by any means is good, and would use it to drive a highly moral socio-economic agenda. Buyvesting would not pose a clear threat to the status quo and would not risk eliciting a hostile response from the financial establishment. The changes made by buyvesting to the financial landscape could therefore be made peacefully, painlessly and seamlessly.

\subsection{Buyvesting Could Succeed Slowly}

The success of buyvesting could be gradual: success would not depend on the support of the majority of the buying or investing population. Even if only a low percentage of consumers were to buy the products recommended by the buyvestment fund, this would suffice to change market conditions and to alter business ethics. That said, a buyvestment fund might benefit from setting a threshold number of buyvestors that would have to be attained before starting financial operations. 


\subsection{A Buyvestment Fund Could Interact in Synergy with Other Institutions}

A buyvestment fund would have what should be a natural ally in pension funds. Awareness of ethical considerations - or of the importance of acknowledging them—is revealed in the Members' Annual Report 2012 of the University Superannuation Scheme (USS), a UK Pension Fund, where it is written: "USS continues to strive to integrate environmental, social and governance issues across the investment portfolio and be a leader in Responsible Investment". An awareness of the potential power of such investment is also evidenced as the report continues with: "Active ownership of invested assets will lead to better returns over the long term". Ironically, however, the USS listed as amongst its largest bond and equity holdings several organizations that face or have faced serious allegations including Royal Dutch Shell [27], HSBC [28], BP [29], British American Tobacco [30], Rio Tinto [31] and BHP Billiton [32]. That said, pension funds can flex their muscles as in the case of the California Public Employees' Retirement System which is part of the Ceres-led coalition (see below) and which called on energy companies to mitigate the risks posed by climate trends pose to their business strategies [33].

Other natural allies include organizations such as Ceres, an institution with the stated mission of working "with leading companies, investors, public interest groups, policymakers and other economic players to advance sustainable solutions that will reduce carbon emissions and other pollutants, protect vital natural resources like water supplies, ensure safe and just working conditions for employees and reduce our reliance on fossil fuels while transitioning to a clean energy economy" [8]. Ceres is likely to be influential insofar as it directs the Investor Network on Climate Risk, in which, it claims, investors collectively manage more than $\$ 10$ trillion in assets. Other possible allies include the Co-operative Group in the UK, which has similar principles to those of buyvesting, and in 2010 had 85,000 employees, 5.8 million members, and a revenue of $£ 13.7$ billion [34], whilst the Credit Mutuel, a cooperative bank in France, in 2013 had 78,000 employees, 30 million customers and member-shareholders, and made a profit of $2 €$ billion [35].

Share ownership is a feature of $14 \%$ of companies in the UK where it involves $22 \%$ of all employees [36]. These employees are likely to be supportive of buyvesting, particularly since their loyalty to and familarity with their companies leads them to invest heavily in company stock (even when this is imprudent) [37]. Finally, community investing, which is but one aspect of socially responsible investing, is reported to have some $\$ 61.4$ billion in managed assets [38].

\section{The Model}

Buyvesting is proposed to change the general behaviour of companies by causing general changes in the attitudes and behaviours of investors and consumers. Such general changes are hard to capture in a model. However, the behaviour of companies is, to a large extent, both caused by and reflected in the ethics of the Members of the Board. This underpins the idea behind the model we develop here that general changes in the behaviour of investors and consumers can be captured by studying specific changes to the composition of the Board, in other words, by studying specific changes in the nature of those who are elected to and evicted from the Board.

\subsection{The Specific Analogy}

To model how the composition of the Board might be changed, we exploited a learning program, Coco, that implements competitive coherence [10] and that has some similarity to Hopfield's network model [39] in its use of a Hebbian learning rule whereby learning occurs as a result of the strengthening of the weights of the links between nodes [40]. The Coco program has a big set of inactive elements from which a small subset of active elements is chosen. An element becomes active when the address of the element is loaded into the Activity Register. The set of all elements (excluding inputs and outputs) corresponds to all those people who are or who could become Board members, the addresses of the elements correspond to their names, the addresses in the Now and Next fields correspond to the names of the people with whom a particular person has a connection, and the addresses in the Activity Register correspond to the names of the members of the Board (see Section 3). Each loading of the Activity Register — and there can be several such loadings between input and output-corresponds to a term of service, after which Board members have to stand down. They can be re-elected after an obligatory period of "inactivity".

In response to a sequence of different inputs, the Coco program learns to give a sequence of appropriate outputs; this is achieved by rewarding and punishing via changes to the connections in the Now and Next fields, and 
hence via changes to the probabilities of elements becoming active [10]. In the analogy, the inputs correspond to the state of the Market and the outputs correspond to the response of the company; these responses can be rewarded or punished depending on the appropriateness of the response (e.g., an input of 1 corresponds to a boom period and the response of 1000 corresponds to a growth strategy, which is rewarded, see below). Members who have participated in a successful period of the Board (input-output sequence in the Activity Register) have patterns of connections that differ from those Members who have participated in unsuccessful periods. Moreover, successful Members have more connections than those that have failed (this is represented by the relative sizes of the Now and Next fields).

A subset of the elements is defined as the buyvestor Club whose members share the buyvesting philosophy and who are tightly connected to one another. An economic crisis that leads to a major change in the composition of the Board is represented by a replacement of some of the elements that are active once the program has learnt (i.e., have their addresses present in the Activity Register at some stage in the sequence of loadings in the learnt state).

\subsection{The Questions}

In the specific case where buyvesting is assessed by its capacity to effect a major change in the composition of a Board, buyvesting is confronted with at least two problems: 1) getting a member of the Club onto the Boardinfiltration - and then 2) getting the other members of the Club onto the Board.

The model may be developed to allow the following questions to be addressed or, at least, clarified. What are the factors that affect the infiltration step and what are the factors that affect the subsequent recruitment of other members of the Club to the Board? Is the probability of a Club member getting onto the Board increased in a time of crisis? Does this probability increase if the people in the system have many connections between one another so that there is likely to be a connection between the Board and the Club? Is strengthening the connections between members of the Club sufficient to change the composition of the Board? Can change be effected progressively without the performance of the company suffering?

\subsection{The Results}

First, we standardized the Coco program by fixing the total elements at 1000 of which three inputs (1, 2 and 3) were chosen to be inputs and another three (998, 999 and 1000) were chosen to be outputs. Coco was set to learn a standard task that required successive inputs of 1, 2, 3, 2, 3 to be responded to with outputs of 1000, 999, 999, 1000 and 998, respectively; this is a difficult task that requires both Now and Next processes because the right response to an input of 2, for example, depends on where 2 lies in the sequence. Second, the Club of potential Board members who would promote buyvesting was defined as those elements from 11 to 100, inclusive. A positive control was then performed to show that the Coco program was capable of escaping from one learnt state into another: when the program had learnt, as shown by the continuous negative slope of the graph after 500 consecutive successful responses (Figure 1(a), top panel on left), a crisis was simulated. This took the form of a temporary, enforced change in the composition of the Board in which several members of the Board were replaced with randomly chosen Club members for a brief time (representing by a single loading of the Activity Register in the program). This temporary change in the example given in Figure 1 is represented by the Board composition going from $(239,681,348,158,799,720,69,814,799,876)$, where there is one Club member (Figure 1(a), top left panel), to (70, 239, 348, 20, 100, 71, 47, 66, 91, 876), where there are 7 Club members (not shown). At the same time as this crisis, the connectivity strength between Club members was increased 20 -fold (that is, the weighting on their connections was increased from 1 to 20), the number of interconnections between Club members was increased so that most Club members were connected to other Club members (the bold, red addresses in the bottom panels of the figures), and, finally, a single member of the Board was replaced at random by a Club member for a 100 time steps to simulate the effects of protracted turbulence of the Market. The initial learnt state of the Board contained 14 Club members (21, 28, 39, 48, 63, 69, 75, 83, 85, 91, 95, 96, 97, 100) out of a sequence of 120 elements, of which 10 were inputs and outputs, whereas the relearnt state of the Board contained 35 Club members (11, 14, 17, 18, 21, 22, 23, 24, 26, 28, 29, 30, 33, 36, 37, 39, 40, 43, 48, 50, 55, 56, 57, 58, 60, 61, 62, 70, 72, 81, 82, 83, 84, 92, 93) (Figure 1(b), top left panel). Despite the strong selection for Club members, one time step in Figure 1(b) has no Club members on the Board; one, technical, reason for this is that someone can only be elected to the Board once in ten time steps and, since there are only 90 Club 
members in the program, a time may occur when no Club members are eligible for election. Note too, that an elected Club member may not have a Now or Next connection to other Club members and hence cannot help.

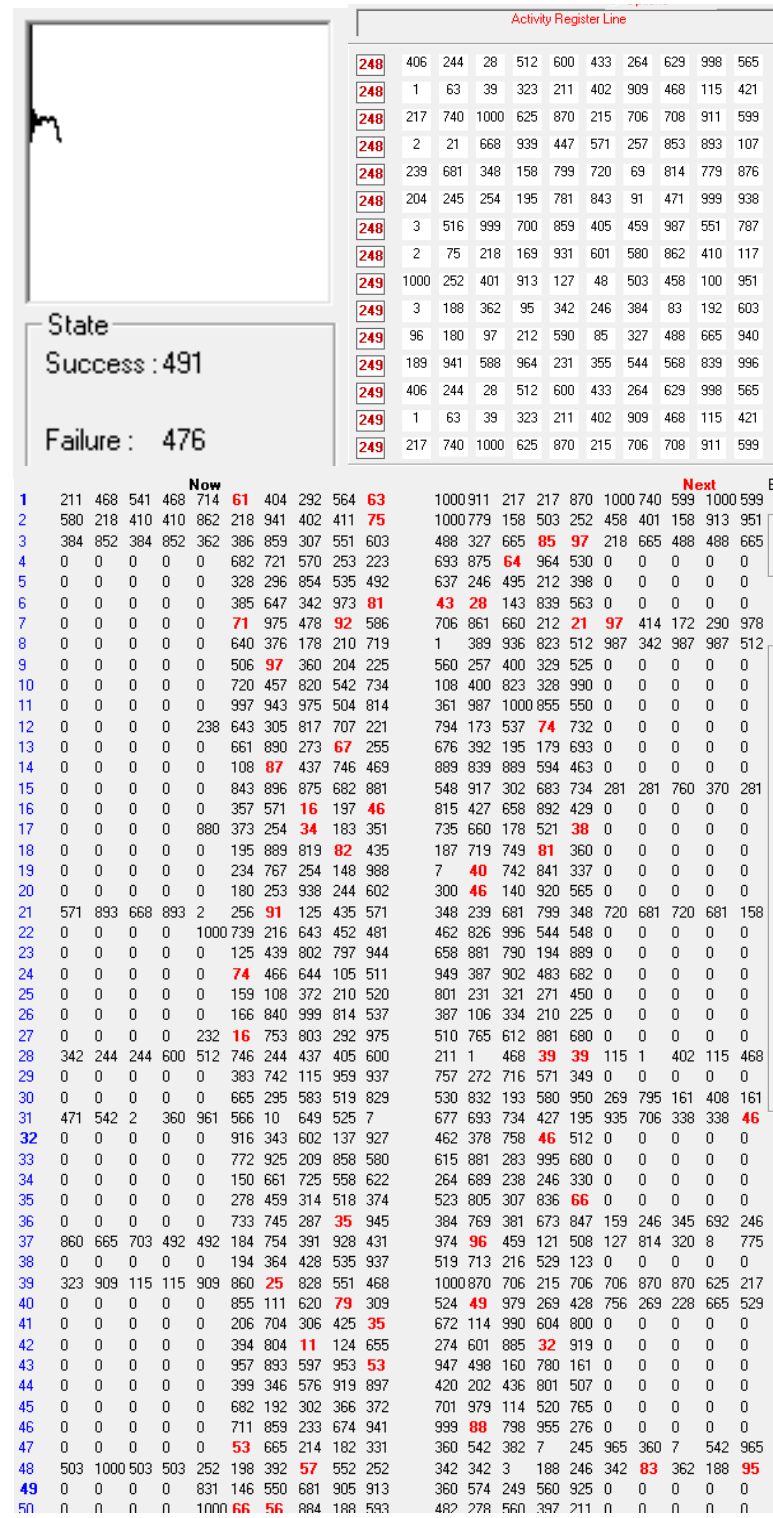

(a)

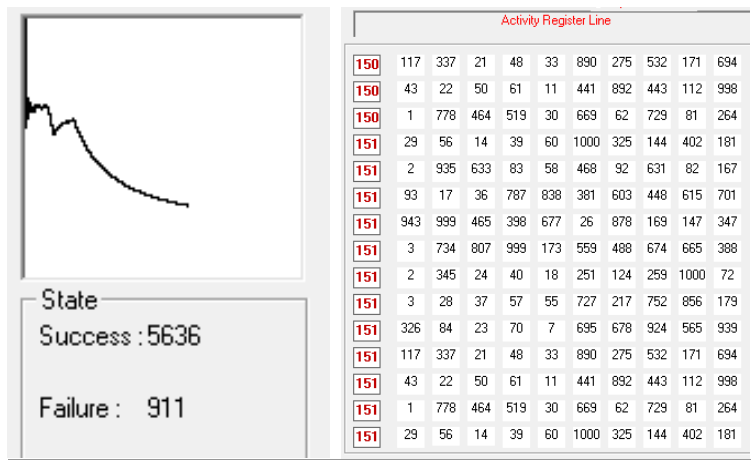

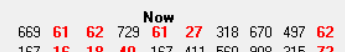

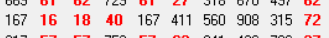
$\begin{array}{llllllllll}217 & 57 & 57 & 752 & 57 & 62 & 941 & 436 & 706 & 37\end{array}$ $\begin{array}{llllllllll}0 & 0 & 0 & 0 & 0 & 682 & 721 & 570 & 253 & 268 \\ 0 & 0 & 0 & 0 & 0 & 679 & 692 & 279 & 804 & 460\end{array}$ $\begin{array}{llllllllll}0 & 0 & 0 & 0 & 0 & 219 & 90 & 994 & 328 & 221\end{array}$ $\begin{array}{lllllllllll}23 & 924 & 326 & 326 & 924 & 843 & 565 & 976 & 629 & 70 \\ 0 & 0 & 0 & 0 & 0 & 426 & 341 & 757 & 887 & 469\end{array}$ $\begin{array}{llllllllll}0 & 0 & 0 & 0 & 0 & 426 & 341 & 757 & 887 & 469 \\ 0 & 0 & 0 & 0 & 0 & 219 & 347 & 823 & 49 & 199\end{array}$ $\begin{array}{llllllllll}0 & 0 & 0 & 0 & 0 & 219 & 347 & 823 & 49 & 199 \\ 0 & 0 & 0 & 0 & 270 & 940 & 457 & 487 & 257 & 151\end{array}$ $\begin{array}{llllllllll}112 & 892 & 43 & 22 & 50 & 39 & 75 & 616 & 252 & 443\end{array}$

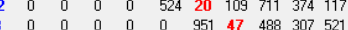

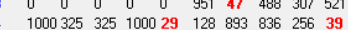

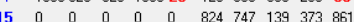

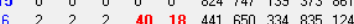
$\begin{array}{lllllllllll}17 & 36 & 448 & 615 & 93 & 36 & 441 & 650 & 334 & 835 & 124 \\ 17 & 361 & 975 & 443 & 615\end{array}$ $\begin{array}{lllllllllll}8 & 40 & 40 & 366 & 177 & 2 & 220 & 873 & 353 & 172 & 40\end{array}$ $\begin{array}{lllllllllll}19 & 0 & 0 & 0 & 0 & 0 & 187 & 599 & 663 & 904 & 103\end{array}$ $\begin{array}{lllllllllll}20 & 0 & 0 & 0 & 0 & 0 & 493 & 848 & 784 & 83 & 359\end{array}$

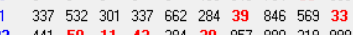
$\begin{array}{llllllllll}441 & 50 & 11 & 43 & 284 & 30 & 857 & 880 & 219 & 998\end{array}$

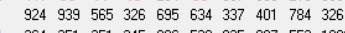

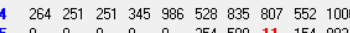
$\begin{array}{llllllllll}0 & 0 & 0 & 0 & 0 & 254 & 500 & 11 & 154 & 893 \\ 147 & 465 & 465 & 169 & 741 & 898 & 198 & 890 & 273 & 347\end{array}$

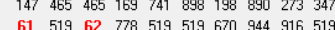
$\begin{array}{llllllllll}61 & 519 & 62 & 778 & 519 & 519 & 670 & 944 & 916 & 519\end{array}$ $\begin{array}{llllllllll}57 & 727 & 856 & 179 & 653 & 871 & 363 & 662 & 545 & 37 \\ 30 & 890 & 890 & 999 & 30 & 798 & 606 & 748 & 81 & 181\end{array}$ $\begin{array}{lllllllllll}30 & 890 & 890 & 999 & 30 & 798 & 606 & 748 & 81 & 18 \\ 0 & 1000 & 181 & 60 & 656 & 404 & 806 & 340 & 1\end{array}$ $\begin{array}{llllllllll}181 & 1000 & 402 & 181 & 60 & 656 & 404 & 806 & 340 & 1 \\ 0 & 0 & 0 & 0 & 0 & 379 & 913 & 296 & 649 & 200\end{array}$ $\begin{array}{llllllllll}0 & 0 & 0 & 0 & 0 & 379 & 913 & 296 & 649 & 200 \\ 0 & 0 & 0 & 0 & 0 & 585 & 735 & 630 & 87 & 553\end{array}$ $\begin{array}{llllllllll}171 & 48 & 171 & 532 & 968 & 107 & 199 & 56 & 844 & 275\end{array}$ $\begin{array}{llllllllll}0 & 0 & 0 & 0 & 0 & 346 & 192 & 624 & 422 & 192\end{array}$ $\begin{array}{lllllllllll}74 & 74 & 778 & 74 & 778 & 267 & 418 & 862 & 12 & 61\end{array}$ $\begin{array}{llllllllll}701 & 17 & 787 & 701 & 838 & 859 & 145 & 6 & 538 & 787\end{array}$ $\begin{array}{llllllllll}57 & 179 & 55 & 55 & 57 & 903 & 171 & 331 & 571 & 752\end{array}$ $\begin{array}{llllllllll}0 & 0 & 0 & 0 & 0 & 807 & 305 & 316 & 484 & 388\end{array}$ $\begin{array}{llllllllll}29 & 144 & 402 & 29 & 1 & 401 & 497 & 964 & 60 & 402\end{array}$ $\begin{array}{llllllllll}260 & 167 & 167 & 167 & 167 & 608 & 907 & 974 & 47 & 1000\end{array}$ $\begin{array}{llllllllll}0 & 0 & 0 & 0 & 0 & 771 & 83 & 438 & 320 & 70\end{array}$

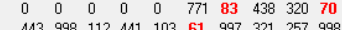
$\begin{array}{lllllllllll}43 & 443 & 998 & 112 & 441 & 103 & 61 & 997 & 321 & 257 & 998 \\ 44 & 0 & 0 & 0 & 0 & 0 & 160 & 19 & 168 & 72 & 458\end{array}$ $\begin{array}{llllllllllll}45 & 0 & 0 & 0 & 0 & 0 & 632 & 534 & 483 & 24 & 35 \\ 46 & 0 & 0 & 0 & 0 & 0 & 807 & 763 & 284 & 485 & 412\end{array}$ $\begin{array}{lllllllllll}46 & 0 & 0 & 0 & 0 & 0 & 807 & 763 & 284 & 485 & 412 \\ 47 & 0 & 0 & 0 & 0 & 379 & 296 & 287 & 115 & 282 & 69\end{array}$ $\begin{array}{llllllllll}532 & 171 & 532 & 337 & 555 & 864 & 110 & 413 & 168 & 337\end{array}$ $\begin{array}{llllllllll}0 & 0 & 0 & 0 & 0 & 340 & 532 & 23 & 810 & 585\end{array}$ $\begin{array}{lllllllllllll}50 & 61 & 112 & 998 & 43 & 692 & 70 & 825 & 305 & 814 & 112\end{array}$ Next $1000144 \quad 325 \quad 29 \quad 60-56 \quad$ B

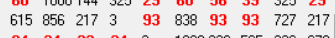
$\begin{array}{llllllllll}84 & 24 & 23 & 24 & 2 & 1000326 & 565 & 326 & 678\end{array}$ $\begin{array}{llllllllll}693 & 875 & 217 & 964 & 530 & 0 & 0 & 0 & 0 & 0 \\ 16 & 246 & 762 & 920 & 426 & 0 & 0 & 0 & 0 & 0\end{array}$ $\begin{array}{llllllllll}984 & 729 & 573 & 93 & 229 & 0 & 0 & 0 & 0 & 0\end{array}$ $\begin{array}{llllllllll}48 & 890 & 48 & 532 & 117 & 117 & 532 & 117 & 532 & 48\end{array}$

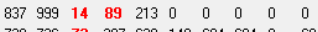
$\begin{array}{llllllllll}739 & 726 & 73 & 397 & 639 & 149 & 694 & 694 & 8 & 694\end{array}$ $\begin{array}{llllllllll}108 & 68 & 823 & 971 & 189 & 0 & 0 & 0 & 0 & 0 \\ 669 & 464 & 464 & 1 & 81 & 464 & 464 & 729 & 519 & 30\end{array}$

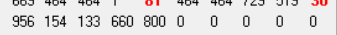

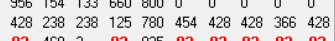
$\begin{array}{llllllllll}82 & 468 & 2 & 83 & 935 & 92 & 92 & 82 & 83 & 82\end{array}$

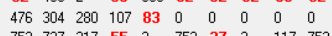

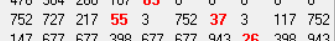
$\begin{array}{llllllllll}37 & 28 & 856 & 179 & 55 & 727 & 37 & 3 & 37 & 37\end{array}$ $\begin{array}{lllllll}67 & 57 & 57 & 900 & 469 & 0\end{array}$

$\begin{array}{lllllll}404 & 140 & 0 & 0 & 0 & 0 & 0\end{array}$ $\begin{array}{lllllllllll}112 & 11 & 892 & 441 & 892 & 112 & 112 & 441 & 892 & 22\end{array}$

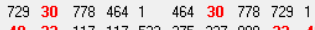
$\begin{array}{llllllllll}48 & 33 & 117 & 117 & 532 & 275 & 337 & 890 & 33 & 48\end{array}$ $\begin{array}{llllllllll}752 & 57 & 727 & 727 & 752 & 3 & 55 & 856 & 727 & 28 \\ 780 & 15 & 840 & 428 & 366 & 0 & 0 & 0 & 0 & 0\end{array}$

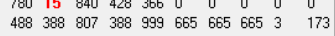

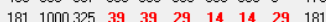

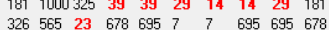
$\begin{array}{llllllllll}326 & 565 & 23 & 678 & 695 & 7 & 7 & 695 & 695 & 678 \\ 82 & 83 & 82 & 935 & 82 & 935 & 83 & 83 & 83 & 633\end{array}$

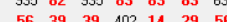

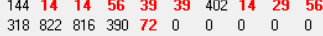
$\begin{array}{llllllllll}332 & 703 & 641 & 66 & 628 & 0 & 0 & 0 & 0 & 0\end{array}$ $\begin{array}{lllllllllll}22 & 892 & 22 & 22 & 61 & 43 & 443 & 43 & 443 & 43 \\ 252 & 638 & 24 & 2 & 42 & 95 & 2 & 49 & 83 & 724\end{array}$

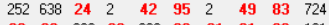
$\begin{array}{llllllllll}29 & 29 & 360 & 60 & 238 & 39 & 81 & 81 & 60 & 181\end{array}$

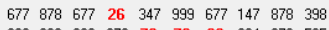

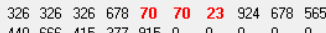

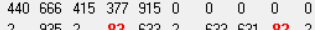
$\begin{array}{llllllllll}2 & 935 & 2 & 83 & 633 & 2 & 633 & 631 & 82 & 2 \\ 179 & 752 & 57 & 55 & 3 & 752 & 179 & 217 & 217 & 57\end{array}$

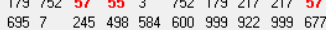
$226 \quad 960113604 \quad 483 \quad 0 \quad 0 \quad 00040$

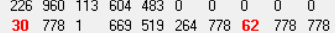

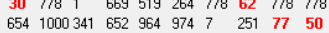

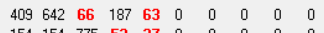
$\begin{array}{llllllllll}154 & 154 & 775 & 53 & 37 & 0 & 0 & 0 & 0 & 0 \\ 55 & 988 & 873 & 85 & 924 & 0 & 0 & 0 & 0 & 0\end{array}$ $\begin{array}{llllllllll}892 & 441 & 50 & 441 & 441 & 50 & 892 & 112 & 43 & 892\end{array}$ $\begin{array}{llllllllll}530 & 244 & 37 & 665 & 89 & 0 & 0 & 0 & 0 & 0\end{array}$

(b)

Figure 1. Changed composition of board. The composition of the Board can be changed by (1) a crisis that inserts a connection to a randomly chosen person into the Now and Next connection fields of half the entire set of people (here 1000), and (2) a temporary replacement of the Board by Club members. (a) Before the crisis. Top left panel, the program has learnt as shown by the negative slope; top right panel, the composition of the Board at consecutive times in this first learnt state: there are 14 Club members present at different times on the Board before the crisis. Bottom panel, the Now and Next connections of the elements 11 to 50 (note that elements 11 to 100 correspond to the Club members); connections to other Club Members are shown in bold red. (b) After the crisis. Top left panel, the crisis is followed by an increase in inappropriate responses (steep curve with positive slope) until the second learnt stage is attained (long curve with negative slope) with a Board that contains 35 Club members. Bottom panel, members of the Club have many more connections to other Club members after the crisis. Parameter values were: eligible people $=1000$; number on Board $=10$; the number of Next and Now connections of each element ranges between 5 and 10; ineligibility for re-election $=10$ time-steps; crisis occurs after 500 consecutive, learnt steps; Club members from 11 to 100; weighting of connections between Club members increases in the crisis from 1, the usual value, to 20; a mutational storm during the crisis inserts a connection to a randomly chosen person into the Now and Next fields of 500 people and then inserts randomly chosen club members into the Board for a single time-step. 


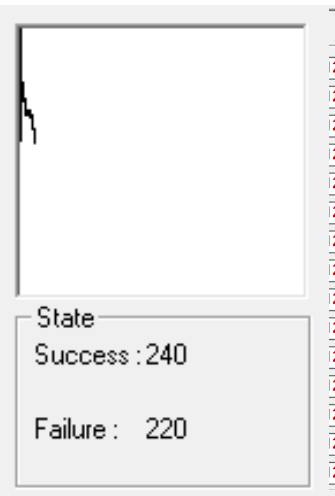

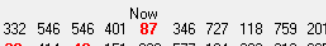
$\begin{array}{llllllllll}30 & 414 & 49 & 151 & 938 & 577 & 184 & 292 & 312 & 665\end{array}$ $\begin{array}{llllllllll}284 & 6 & 563 & 333 & 570 & 579 & 590 & 184 & 666 & 304\end{array}$

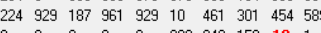
$\begin{array}{llllllllll}0 & 0 & 0 & 0 & 0 & 899 & 849 & 159 & 19 & 1 \\ 563 & 570 & 304 & 284 & 356 & 220 & 530 & 284 & 626 & 356\end{array}$ $\begin{array}{llllllllll}563 & 570 & 304 & 284 & 356 & 220 & 530 & 284 & 626 & 356 \\ 0 & 0 & 0 & 0 & 0 & 718 & 198 & 491 & 348 & 577\end{array}$ $\begin{array}{llllllllll}0 & 0 & 0 & 0 & 0 & 373 & 91 & 245 & 736 & 218\end{array}$

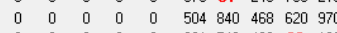

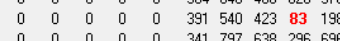

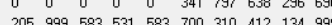
310412134999 $\begin{array}{lllllllllll}3 & 834 & 901 & 901 & 613 & 284 & 760 & 566 & 971 & 194 & 34 \\ 14 & 0 & 0 & 0 & 0 & 0 & 659 & 935 & 302 & 31 & 180\end{array}$ $\begin{array}{lllllllllll}14 & 0 & 0 & 0 & 0 & 0 & 659 & 935 & 302 & 31 & 180 \\ 15 & 0 & 0 & 0 & 0 & 0 & 871 & 727 & 456 & 896 & 855\end{array}$ $\begin{array}{ccccccccccc}16 & 0 & 0 & 0 & 0 & 0 & 184 & 66 & 419 & 96 & 534 \\ 17 & 0 & 0 & 0 & 0 & 0 & 621 & 119 & 448 & 676 & 839\end{array}$ $\begin{array}{lllllllllll}17 & 0 & 0 & 0 & 0 & 0 & 621 & 119 & 448 & 676 & 839\end{array}$ $\begin{array}{llllllllll}0 & 0 & 0 & 0 & 0 & 363 & 732 & 889 & 686 & 295 \\ 0 & 0 & 0 & 0 & 2 & 313 & 396 & 217 & 372 & 97\end{array}$ $\begin{array}{llllllllll}0 & 0 & 0 & 0 & 0 & 124 & 715 & 675 & 156 & 106\end{array}$ $\begin{array}{llllllllll}0 & 0 & 0 & 0 & 0 & 273 & 991 & 21 & 863 & 132\end{array}$ $\begin{array}{llllllllll}414 & 414 & 2 & 71 & 346 & 334 & 248 & 512 & 804 & 15\end{array}$ $\begin{array}{lllllllll}0 & 0 & 0 & 0 & 0 & 898 & 1000515 & 6 & 672\end{array}$ $\begin{array}{lllllllllll}174 & 506 & 174 & 174 & 266 & 924 & 584 & 575 & 555 & 275\end{array}$ $\begin{array}{lllllllllll}25 & 0 & 0 & 0 & 0 & 333 & 423 & 355 & 743 & 305 & 107 \\ 26 & 151 & 12 & 124 & 845 & 211 & 117 & 562 & 988 & 882 & 508\end{array}$ $\begin{array}{lllllllllll}26 & 151 & 12 & 124 & 845 & 211 & 117 & 562 & 988 & 882 & 508 \\ 27 & 0 & 0 & 0 & 0 & 0 & 632 & 222 & 158 & 921 & 190\end{array}$ $\begin{array}{lllllllllll}27 & 0 & 0 & 0 & 0 & 0 & 632 & 222 & 158 & 921 & 190 \\ 28 & 0 & 0 & 0 & 0 & 0 & 90 & 222 & 117 & 515 & 655 \\ 29 & 0 & 0 & 0 & 0 & 0 & 787 & 722 & 319 & 305 & 470\end{array}$ $\begin{array}{lllllllllllll}492 & 492 & 346 & 346 & 874 & 643 & 109 & 516 & 857 & 346\end{array}$ $\begin{array}{llllllllll}0 & 0 & 0 & 0 & 0 & 256 & 992 & 78 & 835 & 846 \\ 0 & 0 & 0 & 0 & 0 & 670 & 429 & 509 & 734 & 825\end{array}$ $\begin{array}{llllllllll}0 & 0 & 0 & 0 & 0 & 457 & 212 & 83 & 436 & 998\end{array}$ $\begin{array}{lllllllllll}626 & 134 & 585 & 626 & 585 & 86 & 910 & 6 & 214 & 601\end{array}$ $\begin{array}{lllllllllll}0 & 0 & 0 & 0 & 0 & 288 & 651 & 867 & 160 & 393\end{array}$ $\begin{array}{lllllllllll}0 & 0 & 0 & 0 & 234 & 934 & 929 & 308 & 324 & 293\end{array}$ $\begin{array}{lllllllllll}429 & 124 & 429 & 155 & 155 & 299 & 925 & 312 & 416 & 809 \\ 0 & 0 & 0 & 0 & 95 & 894 & 580 & 963 & 423 & 573\end{array}$

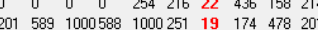
$\begin{array}{lllllllll}0 & 01 & 0 & 0 & 057 & 295 & 239 & 974 & 452\end{array}$ $\begin{array}{lllllllll}0 & 0 & 0 & 0 & 385 & 567 & 427 & 631 & 465\end{array}$ $\begin{array}{llllllllll}0 & 0 & 0 & 0 & 0 & 873 & 113 & 82 & 660 & 79\end{array}$ $\begin{array}{lllllllllll}44 & 0 & 0 & 0 & 0 & 0 & 596 & 126 & 432 & 404 & 596 \\ 45 & 0 & 0 & 0 & 0 & 0 & 402 & 54 & 563 & 627 & 85\end{array}$ $\begin{array}{lllllllllll}45 & 0 & 0 & 0 & 0 & 0 & 402 & 54 & 563 & 627 & 85 \\ 46 & 0 & 0 & 0 & 0 & 0 & 329 & 501 & 233 & 138 & 450\end{array}$ $\begin{array}{lllllllllll} & 0 & 0 & 0 & 0 & 0 & 329 & 591 & 233 & 138 & 450\end{array}$ $\begin{array}{llllllllllll}48 & 784 & 784 & 568 & 9 & 784 & 437 & 726 & 192 & 288 & 155 \\ 49 & 492 & 346 & 151 & 71 & 30 & 113 & 20 & 640 & 692 & 71\end{array}$

(a)
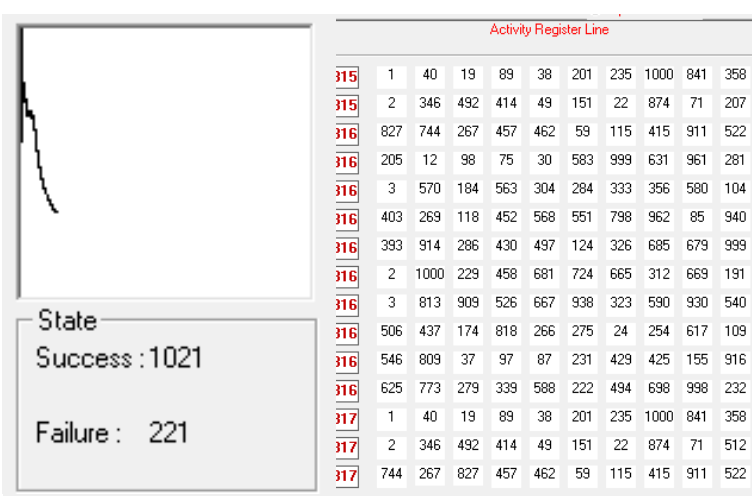

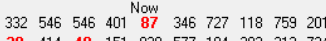
$292 \quad 312724$ $\begin{array}{llllllllll}284 & 6 & 563 & 333 & 570 & 579 & 590 & 184 & 666 & 590\end{array}$ $\begin{array}{llllllllll}224 & 929 & 187 & 961 & 929 & 10 & 461 & 301 & 454 & 589\end{array}$ $\begin{array}{llllllll}7 & 730 & 284 & 626 & 356\end{array}$ $\begin{array}{lllllllll}0 & 0 & 0 & 0 & 373 & 91 & 245 & 736 & 218\end{array}$

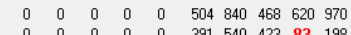
$\begin{array}{llllllllll}0 & 0 & 0 & 0 & 0 & 391 & 540 & 423 & 83 & 198 \\ 0 & 0 & 0 & 0 & 0 & 341 & 797 & 638 & 296 & 696\end{array}$

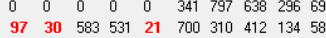
$\begin{array}{llllllllll}97 & 30 & 583 & 531 & 21 & 700 & 310 & 412 & 134 & 583 \\ 0 & 0 & 0 & 0 & 0 & 760 & 639 & 971 & 194 & 37\end{array}$ \begin{tabular}{lllllllllll}
13 & 0 & 0 & 0 & 0 & 0 & 760 & 639 & 971 & 194 & 37 \\
\hline & 0 & 0 & 0 & 0 & 0 & 659 & 935 & 75 & 28 & $\mathbf{8 7}$
\end{tabular} $\begin{array}{lllllllllll}14 & 0 & 0 & 0 & 0 & 0 & 659 & 935 & 75 & 28 & 87 \\ 15 & 0 & 0 & 0 & 0 & 0 & 871 & 727 & 456 & 896 & 855\end{array}$ $\begin{array}{lllllllllll}5 & 0 & 0 & 0 & 0 & 0 & 871 & 727 & 456 & 896 & 855 \\ 6 & 0 & 0 & 0 & 0 & 0 & 184 & 66 & 419 & 96 & 52 \\ 7 & 0 & 0 & 0 & 0 & 0 & 621 & 119 & 448 & 676 & 839\end{array}$

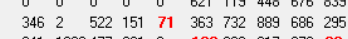
$\begin{array}{llllllll}841 & 1000477 & 201 & 2 & 100396 & 217 & 372 & 89\end{array}$ $\begin{array}{llllllllll}71 & 346 & 492 & 71 & 71 & 124 & 29 & 89 & 156 & 106 \\ 205 & 631 & 583 & 531 & 65 & 273 & 65 & 21 & 863 & 631\end{array}$ $\begin{array}{llllllllll}205 & 631 & 583 & 531 & 65 & 273 & 65 & 21 & 863 & 631\end{array}$ $\begin{array}{llllllllll}414 & 414 & 2 & 71 & 346 & 334 & 95 & 512 & 804 & 151 \\ 0 & 0 & 0 & 0 & 0 & 898 & 1000515 & 6 & 672\end{array}$ $\begin{array}{lllllllllll}174 & 506 & 174 & 174 & 51 & 924 & 584 & 575 & 555 & 506\end{array}$ $\begin{array}{llllllllll}0 & 0 & 0 & 0 & 333 & 423 & 355 & 40 & 305 & 107\end{array}$

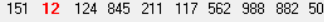
$\begin{array}{llllllllll}0 & 0 & 0 & 0 & 0 & 632 & 222 & 158 & 921 & 190\end{array}$ $\begin{array}{llllllllll}0 & 0 & 0 & 0 & 0 & 87 & 37 & 96 & 515 & 655\end{array}$ $\begin{array}{lllllllllll}52 & 492 & 346 & 83 & 65 & 643 & 109 & 516 & 857 & 12\end{array}$ $\begin{array}{llllllllll}52 & 492 & 346 & 83 & 65 & 643 & 109 & 516 & 857 & 12 \\ 0 & 0 & 0 & 0 & 0 & 256 & 12 & 78 & 54 & 846\end{array}$ $\begin{array}{llllllllll}0 & 0 & 0 & 0 & 0 & 256 & 12 & 78 & 54 & 846 \\ 0 & 0 & 0 & 0 & 0 & 670 & 429 & 30 & 734 & 825\end{array}$ $\begin{array}{llllllllll}155 & 86 & 86 & 86 & 429 & 457 & 212 & 83 & 436 & 37\end{array}$

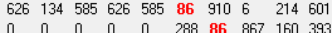
$\begin{array}{llllllllll}87 & 425 & 231 & 87 & 87 & 299 & 425 & 312 & 927 & 809\end{array}$ $\begin{array}{llllllllll}87 & 425 & 231 & 87 & 87 & 299 & 425 & 312 & 927 & 809 \\ 10001000 & 201 & 19 & 95 & 73 & 580 & 963 & 423 & 1000\end{array}$ $\begin{array}{lllllllllll}0 & 0 & 0 & 0 & 70 & 216 & 61 & 71 & 158 & 41\end{array}$ $\begin{array}{lllllllll}201 & 89 & 38 & 588 & 1000251 & 19 & 174 & 478 & 201\end{array}$ $\begin{array}{llllllllll}267 & 827 & 115 & 267 & 857 & 857 & 295 & 239 & 974 & 59\end{array}$ $\begin{array}{llllllllll}999 & 21 & 281 & 75 & 65 & 385 & 567 & 427 & 37 & 75\end{array}$ $\begin{array}{lllllllllll}0 & 0 & 0 & 0 & 0 & 873 & 113 & 82 & 660 & 79\end{array}$ $\begin{array}{lllllllllll}43 & 0 & 0 & 0 & 0 & 0 & 873 & 113 & 82 & 660 & 79 \\ 44 & 0 & 0 & 0 & 0 & 0 & 596 & 126 & 432 & 404 & 596\end{array}$ $\begin{array}{llllllllll}0 & 0 & 0 & 0 & 0 & 63 & 54 & 563 & 627 & 164 \\ 0 & 0 & 0 & 0 & 0 & 329 & 501 & 233 & 138 & 450\end{array}$ $\begin{array}{llllllllll}0 & 0 & 0 & 0 & 0 & 329 & 501 & 233 & 138 & 450 \\ 0 & 0 & 0 & 0 & 0 & 69 & 69 & 40 & 382 & 198\end{array}$

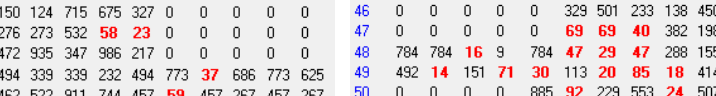

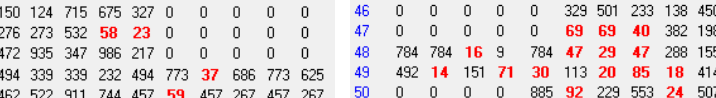
$\begin{array}{llllllllll}494 & 339 & 339 & 232 & 494 & 773 & 37 & 686 & 773 & 625 \\ 462 & 522 & 911 & 744 & 457 & 59 & 457 & 267 & 457 & 267\end{array}$

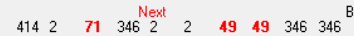

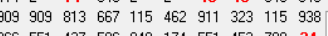

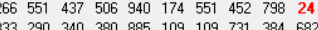
$\begin{array}{llllllllll}333 & 290 & 340 & 380 & 885 & 109 & 109 & 731 & 384 & 682 \\ 820 & 527 & 51 & 955 & 76 & 297 & 1000271 & 216 & 190\end{array}$ $\begin{array}{llllllllll}551 & 527 & 51 & 95 & 76 & 297 & 1000271 & 216 & 190 & 0\end{array}$ $\begin{array}{llllllllll}694 & 739 & 134 & 683 & 771 & 0 & 0 & 0 & 0 & 0\end{array}$

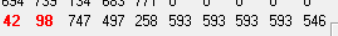
$\begin{array}{llllllllll}33 & 644 & 193 & 102 & 823 & 0 & 0 & 0 & 0 & 0 \\ 373 & 700 & 985 & 397 & 160 & 0 & 0 & 0 & 0 & 0\end{array}$

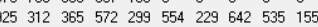
$\begin{array}{llllllllll}563 & 356 & 570 & 284 & 356 & 570 & 563 & 184 & 304 & 356\end{array}$ $\begin{array}{llllllllll}97 & 548 & 586 & 260 & 2 & 0 & 0 & 0 & 0 & 0 \\ 91 & 185 & 54 & 67 & 978 & 356 & 563 & 570 & 356 & 104\end{array}$ $\begin{array}{llllllllll}91 & 185 & 54 & 67 & 978 & 356 & 563 & 570 & 356 & 104 \\ 220 & 65 & 540 & 465 & 690 & 0 & 0 & 0 & 0 & 0\end{array}$

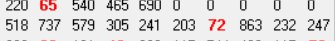
$\begin{array}{llllllllll}202 & 30 & 181 & 42 & 989 & 115 & 744 & 462 & 115 & 59\end{array}$ $\begin{array}{llllllllll}151 & 22 & 492 & 346 & 49 & 414 & 346 & 49 & 151 & 414 \\ 501 & 316 & 235 & 145 & 557 & 115 & 827 & 59 & 98 & 457\end{array}$

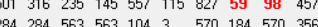

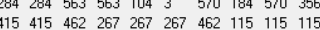
$\begin{array}{llllllllll}24 & 21 & 762 & 267 & 267 & 267 & 462 & 115 & 115 & 115 \\ 25 & 201 & 590 & 194 & 615 & 999 & 194\end{array}$ $\begin{array}{llllllllll}37 & 546 & 429 & 231 & 809 & 429 & 546 & 429 & 231 & 231\end{array}$ $\begin{array}{llllllllll}20 & 900 & 32 & 41 & 437 & 0 & 0 & 0 & 0 & 0\end{array}$ $\begin{array}{llllllllll}83 & 436 & 643 & 50 & 19 & 429 & 120 & 248 & 214 & 19\end{array}$ $\begin{array}{llllllllll}583 & 488 & 39 & 57 & 99 & 0 & 0 & 0 & 0 & 0\end{array}$ $\begin{array}{lllllllllll}570 & 565 & 570 & 551 & 696 & 84 & 654 & 709 & 46 & 999\end{array}$

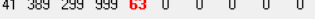
$\begin{array}{llllllllll}580 & 356 & 184 & 563 & 563 & 333 & 356 & 492 & 184 & 356\end{array}$ $\begin{array}{llllllllll}814 & 725 & 622 & 463 & 626 & 0 & 0 & 0 & 0 & 0\end{array}$

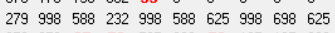
$\begin{array}{llllllllllll}652 & 353 & 95 & 58 & 795 & 389 & 73 & 185 & 185 & 389\end{array}$ $\begin{array}{llllllllll}721 & 901 & 85 & 56 & 94 & 810 & 47 & 18 & 810 & 1\end{array}$ $\begin{array}{llllllllll}74 & 83 & 379 & 160 & 394 & 0 & 0 & 0 & 0 & 0\end{array}$

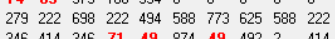

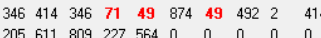
$\begin{array}{llllllllll}205 & 611 & 809 & 227 & 564 & 0 & 0 & 0 & 0 & 0 \\ 2 & 414 & 2 & 492 & 151 & 492 & 49 & 49 & 874 & 414\end{array}$ $\begin{array}{llllllllll}999 & 281 & 281 & 999 & 999 & 961 & 531 & 583 & 12 & 631\end{array}$ $\begin{array}{llllllllll}46 & 304 & 301 & 736 & 612 & 284 & 284 & 333 & 356 & 304\end{array}$

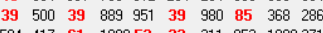

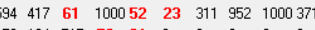
$\begin{array}{llllllllll}150 & 124 & 715 & 72 & 21 & 0 & 0 & 0 & 0 & 0 \\ 276 & 273 & 532 & 58 & 81 & 0 & 0 & 0 & 0 & 0\end{array}$

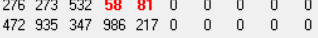

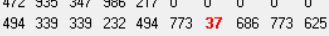
$\begin{array}{llllllllll}462 & 462 & 744 & 744 & 457 & 59 & 457 & 267 & 457 & 457\end{array}$

(b) 232494232588494773222625339998

Figure 2. An increased weighting between Club members is sufficient to change the composition of the Board once the Board is stable. (a) Before the increase. (b) After the increase. Parameter values as in Figure 1 except that the Club was increased to 90 members, the weighting between Club members was increased from 1 to 20 at the crisis and there was no forced change in the Board at the crisis (i.e., no insertion of a new line of randomly chosen Club addresses into the Activity Register).

their election directly, as is the case with the Next connections of Club member 26 (bottom panel of Figure 1(b)). In principle, therefore, the program can model the process of changing the composition of the Board to one in which the Board is dominated by Club members.

The above, successful change in the composition of the Board (Figure 1) required a major crisis in the form of a temporary change (single loading of the Activity Register). This crisis could correspond to an event leading to the empowerment of the Club and the resignation of the Board. Possible examples of such events should include the response of mining companies to the assassination of local populations, and of banks to money laundering. However, the program shows that to find a new learnt state (i.e., to cause a permanent change in the Board that results in successful performance) requires a period of re-learning (i.e., going through a period when 
the company fails to respond adequately to the Market) that may be long. Such a period would menace the survival of the company. We therefore explored whether the Board could be changed without the major crisis.

To test whether the composition of the Board could be changed significantly without a crisis - essentially, by an increase in connectivity strength alone-the program remained in the first learnt state for 500 steps and then the weighting on the connections between Club members - and only between Club members-was suddenly increased 20-fold. This resulted in a change in the composition (Figure 2) with the number of Club members on the Board increasing from $11(6,12,22,24,30,37,40,49,59,71,85,98)$ to $17(12,19,22,24,30,37,38,40$, $49,59,71,75,85,87,89,97,98)$. Importantly, this increase was achieved without a period of bad responses to the Market necessitating re-learning, that is, the composition of the Board was changed without incurring a drop in performance.

\section{Discussion}

The process in the global market whereby "the cheapest takes all" poses a major problem to many people as this process is seen as inescapable. The preference of consumers for the cheapest products pushes down prices and hence wages and, insofar as consumers are producers, the resulting reduction in wages strengthens their preference for the cheapest products. Underpinning this preference is the seemingly universal ethic that competition is good and that profits should be maximized irrespective of social and environment considerations.

The buyvesting approach we advocate here harnesses the power of positive feedback to mount a challenge to the idea of the inevitability of the "cheapest takes all" scenario. Buyvesting would achieve this by reaching a population that other investment schemes cannot. This is the population of the political Left, a population comprising hundreds of millions of people who want to change the way the global market operates and who are uneasy with—if not hostile to- the financial sector.

Although there are many well-meaning financial institutions, to our knowledge, no financial organization comparable to a buyvestment fund exists. That does not mean that a buyvestment fund would be isolated. There are many charitable associations and NGOs that might be expected to encourage buyvesting. And pension funds might be pressured by their members to lend a buyvesting flavor to their investments by joining a buyvestment fund.

Shared reality theory [19] helps explain why when a belief system is held by many powerful individuals it acquires an inertia that makes it difficult to change even though it is an unreality that is shared. To have an idea of whether buyvesting might actually succeed in helping change the prevailing socio-economic climate, we suggest that it might be useful to model market dynamics with reference to shared reality theory. Here, we have shown how such modeling might exploit a program that implements competitive coherence. The results (Figure 1 and Figure 2), together with others, suggest that four factors are important in permitting a tightly connected group of buyvesting supporters (the Club) to take over the Board without a crisis leading to a long series of bad decisions. First, Club members must be present on a successful Board (i.e., there must be Club elements present somewhere in the sequence of steps in the initial learnt state); if no Club member is present, strengthening the connectivity among these members can have no effect. Second, the connection strength of a Club member on the Board for another Club member must be greater than the connections to other members of the Board in the successful state; in other words, the weighting in favor of Club-Club connections over other connections must be sufficient. Third, the position in the election to the Board is important since a Club member who is elected last cannot influence the composition of the Board in that particular time step. Fourth, the relative proportions of the numbers of Club members are of eligible candidates and of the Board size matter; this is because, for example, once a Member has served on the Board, the Member cannot serve again for another ten times steps.

\section{References}

[1] Wikipedia. http://en.wikipedia.org/wiki/Economy

[2] Piketty, T. and Saez, E. (2003) Income Inequality in the United States, 1913-1998. The Quarterly Journal of Economics, 118, 1-41. http://dx.doi.org/10.1162/00335530360535135

[3] Bowles, S. and Park, Y. (2005) Emulation, Inequality and Work Hours: Was Thorsten Veblen Right? The Economic Journal, 115, F397-F412. http://dx.doi.org/10.1111/j.1468-0297.2005.01042.x

[4] Krugman, P.R. (2008) Trade and Wages, Reconsidered. Brookings Papers on Economic Activity, 39, $103-154$. http://dx.doi.org/10.1353/eca.0.0006 
[5] Wilkinson, R. and Pickett, K. (2009) The Spirit Level: Why Greater Equality Makes Societies Stronger. Bloomsbury Press, New York.

[6] Roine, J. and Waldenström, D. (2014) Long-Run Trends in the Distribution of Income and Wealth. IZA Discussion Paper, 8157, 1-151.

[7] Pickett, K.E. and Wilkinson, R.G. (2015) Income Inequality and Health: A Causal Review. Social Science \& Medicine, 128, 316-326. http://dx.doi.org/10.1016/j.socscimed.2014.12.031

[8] Ceres (2014) Ceres 25 Years. http://www.ceres.org/

[9] Tilani, J. and Najamuddin, M. (2014) A Review of Adaptive Bayesian Modeling for Time Series Forecasting. Journal of Applied Environmental and Biological Sciences, 4, 99-106.

[10] Norris, V., Engel, M. and Demarty, M. (2012) Modelling Biological Systems with Competitive Coherence. Advances in Artificial Neural Systems, 2012, Article ID: 703878. http://dx.doi.org/10.1155/2012/703878

[11] Zuppo, P. (2015) Why Is President Obama Appearing at a Nike Event on May 8? https://disqus.com/by/pamelazuppo/

[12] Kimball, A.M., Arima, Y. and Hodges, J.R. (2005) Trade Related Infections: Farther, Faster, Quieter. Globalization and Health, 1, 3. http://dx.doi.org/10.1186/1744-8603-1-3

[13] Ferguson, N.M., Ghani, A.C., Donnelly, C.A., Hagenaars, T.J. and Anderson, R.M. (2002) Estimating the Human Health Risk from Possible BSE Infection of the British Sheep Flock. Nature, 415, 420-424. http://dx.doi.org/10.1038/nature709

[14] Johnson, L., Grant, J. and Low, L.P. (2014) Two Degrees of Separation: Ambition and Reality. Pricewa-Terhouse Coopers, 1-18.

[15] Arnold, K.E., Brown, A.R., Ankley, G.T. and Sumpter, J.P. (2014) Medicating the Environment: Assessing Risks of Pharmaceuticals to Wildlife and Ecosystems. Philosophical Transactions of the Royal Society B, 369, Article ID: 20130569. http://dx.doi.org/10.1098/rstb.2013.0569

[16] Jambeck, J.R., Geyer, R., Wilcox, C., Siegler, T.R., Perryman, M., Andrady, A., Narayan, R. and Law, K.L. (2015) Marine Pollution. Plastic Waste Inputs from Land into the Ocean. Science, 347, 768-771. http://dx.doi.org/10.1126/science.1260352

[17] Norris, V. (2014) What Properties of Life Are Universal? Substance-Free, Scale-free Life. Origins of Life and Evolution of Biospheres, 44, 363-367. http://dx.doi.org/10.1007/s11084-015-9432-7

[18] Norris, V. (1998) Modelling E. coli: The Concept of Competitive Coherence. Comptes Rendus de l'Académie des Sciences: Series III—Sciences de la Vie, 321, 777-787. http://dx.doi.org/10.1016/S0764-4469(98)80018-8

[19] Conley, T.D., Rabinowitz, J.L. and Hardin, C.D. (2010) O. J. Simpson as Shared (And Unshared) Reality: The Impact of Consensually Shared Beliefs on Interpersonal Perceptions and Task Performance in Different- and Same-Ethnicity Dyads. Journal of Personality and Social Psychology, 99, 452-466. http://dx.doi.org/10.1037/a0019274

[20] Hmielowski, J.D., Feldman, L., Myers, T.A., Leiserowitz, A. and Maibach, E. (2014) An Attack on Science? Media Use, Trust in Scientists, and Perceptions of Global Warming. Public Understanding of Science, 23, 866-883.

[21] Publique, O. https://opinionpublique.wordpress.com/tag/front-de-gauche/.

[22] YouGov (2012) YouGov/Sunday Times Survey Results.

[23] CREDO (2015) http://www.credomobile.com/mission/home.

[24] Care2 (2013) Consumers Have the Power. Companies Quietly Change Harmful Ingredients. http://www.care2.com/greenliving/consumers-have-the-power-companies-quietly-change-harmful-ingredients-2.html

[25] Choi, C. (2014) Coke, Pepsi Dropping “BVO” from All Drinks. http://bigstory.ap.org/article/mtn-dew-latest-drop-controversial-ingredient

[26] Blacklistic (2015) http://www.blacklistic.fr/.

[27] Research, A.A.E. (2014) Ogoni Protests Escalate in Nigeria as Shell Fails to Implement UNEP Report. http://platformlondon.org/2013/12/11/ogoni-protests-escalate-in-nigeria-as-shell-fails-to-implement-unep-report/

[28] Mongabay (2013) HSBC Orders Review of Its Lending to Rainforest Logging Companies. http://news.mongabay.com/2013/05/hsbc-orders-review-of-its-lending-to-rainforest-logging-companies/

[29] Hertsgaard, M. (2013) What BP Doesn't Want You to Know about the 2010 Gulf Spill. http://www.newsweek.com/what-bp-doesnt-want-you-know-about-2010-gulf-spill-63015

[30] Centers for Disease Control and Prevention (2013) Tobacco-Related Mortality. http://www.cdc.gov/tobacco/data_statistics/fact_sheets/health_effects/tobacco_related_mortality/

[31] London Mining Network (2013) Rio Tinto Accused of Environmental and Human Rights Breaches. 
http://londonminingnetwork.org/2013/04/rio-tinto-accused-of-environmental-and-human-rights-breaches/

[32] The Guardian (2013) BHP Billiton: Climate Change Leader or Laggard? http://www.theguardian.com/sustainable-business/blog/bhp-billiton-climate-change-leader-laggard

[33] CalPER System (2015) CalPERS Supports Climate Change Reporting Resolution at BP Annual Shareowner Meeting. http://www.calpers.ca.gov/index.jsp?bc=/about/newsroom/news/climate-change-reporting-resolution.xml

[34] The Co-Operative Group (2010) Building a Better Society.

[35] Mutuel, C. (2014) Chiffres-clés Groupe Credit Mutuel. 1-2.

[36] Conyon, M.J. and Freeman, R.B. (2001) Shared Modes of Compensation and Firm Performance. UK Evidence National Bureau of Economic Research, Working Paper 8448, 1-50.

[37] Pendleton, A. (2006) Who Invests Too Much in Employer Stock, and Why Do They Do It? Some Evidence from UK Stock Ownership Plans. Working Paper, Department of Management Studies, University of York, York, 1-32.

[38] Chamberlain, M. (2013) Socially Responsible Investing: What You Need to Know. http://www.forbes.com/sites/feeonlyplanner/2013/04/24/socially-responsible-investing-what-you-need-to-know/

[39] Hopfield, J.J. (1982) Neural Networks and Physical Systems with Emergent Collective Computational Abilities. Proceedings of the National Academy of Sciences of the United States of America, 79, 2554-2558. http://dx.doi.org/10.1073/pnas.79.8.2554

[40] Hebb, D.O. (1949) The Organization of Behavior. Wiley and Sons, New York. 